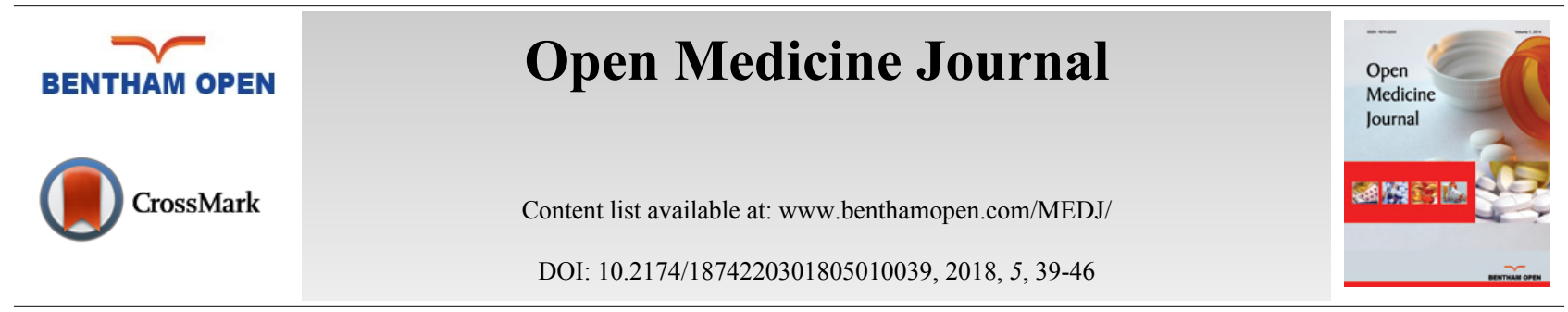

REVIEW ARTICLE

\title{
Association of Mannose-Binding Lectin Gene Polymorphisms with Liver Diseases: A Review
}

\author{
Robert S. Lo ${ }^{1,2, *}$, Andrew S. Austin ${ }^{1}$ and Jan G. Freeman ${ }^{1}$ \\ ${ }^{I}$ Royal Derby Hospital, Derby DE22 3NE, United Kingdom \\ ${ }^{2}$ Tan Tock Seng Hospital, 11 Jalan Tan Tock Seng, 308433, Singapore
}

Received: December 21, 2017

Revised: April 14, 2018

Accepted: July 23, 2018

\begin{abstract}
Mannose-Binding Lectin (MBL) is a member of the collectin family and is an important protein in the immune system. It is a pathogen pattern-recognition molecule that binds to specific carbohydrate motifs on the surface of many pathogens. MBL activates complement via lectin pathway. Single nucleotide polymorphisms in the MBL gene influence serum MBL concentration and function. MBL deficiencies increase the risk of infection and disease-specific complications, especially in those who are already immune compromised with pre-existing conditions. This review discusses the molecular genetics of human MBL and the association of MBL polymorphisms with liver diseases including liver fibrosis, viral hepatitis B, viral hepatitis C, and infection post-liver transplantation.
\end{abstract}

Keywords: Mannose binding lectin, Genetic polymorphism, Complement, Hepatitis B, Hepatitis C, Liver fibrosis, Liver transplantation.

\section{MBL PROTEIN}

The complement system, a major component of innate immunity, provides immediate defence against infection and has a pro-inflammatory response. It consists of plasma and membrane proteins, which mediate 3 pathways, namely classical, alternative and the most recently described lectin [1]. Activation of these pathways of cascading enzymatic reactions results in the deposition of fragments that promote inflammatory and immune response. The classical pathway is activated when Immunoglobulin M or Immunoglobulin $\mathrm{G}$ antibody bind to antigens such as viruses and bacteria that the resulting immune complexes are recognised by C1q, the first component of the classical pathway. The activation of lectin pathway is similar to the classical pathway except that pathogens are directly recognised by a lectin, which includes MBL. MBL is an equivalent of C1q.

Lectins are associated with MBL associated serine proteases (MASPs) that are structurally and functionally similar to $\mathrm{C} 1 \mathrm{q}$-associated proteases $\mathrm{C} 1 \mathrm{r}$ and $\mathrm{C} 1 \mathrm{~s}$. MASPs also cleave $\mathrm{C} 2$ and $\mathrm{C} 4$. The major effect of the complement system, regardless of the pathway, is the deposition of the complement fragment $\mathrm{C} 3 \mathrm{~b}$ on the target (Fig. 1). The effects are membrane modification and promotion of the inflammatory response. Complement fragments including $\mathrm{C} 3 \mathrm{~b}$ deposit in large numbers on microbes and unwanted materials such as apoptotic cells and necrotic tissue. This coating or opsonisation of bacteria and altered-self elements allows specific receptors on peripheral blood cells, especially phagocytes, to bind these ligands. Additionally, activation of complement results in the formation of the membrane attack complexes (C5b-9), which perturb the bacterial cell membrane, thereby causing lysis of the microbes. Activation of the complement system leads to the release of pro-inflammatory peptides. Additionally, complement is also bactericidal as $\mathrm{C} 3 \mathrm{a}$ and $\mathrm{C} 4 \mathrm{a}$ directly kill microorganisms [2].

\footnotetext{
* Address correspondence to this author at the Tan Tock Seng Hospital, 11 Jalan Tan Tock Seng, 308433, Singapore; Tel: +65 63577897; E-mail: robertlo@doctors.org.uk
} 


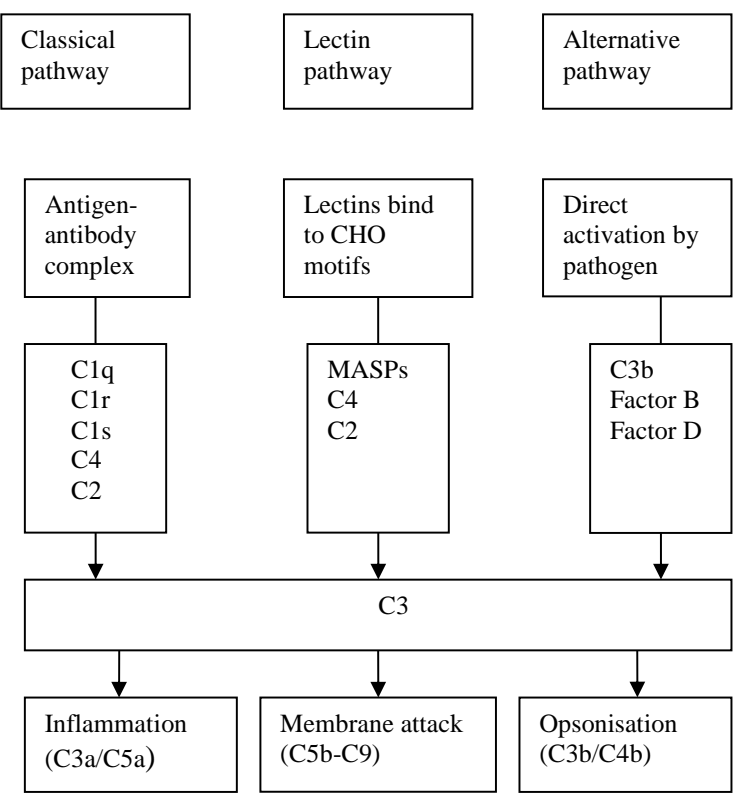

Fig. (1). Classical, lectin and alternative pathways of complement activation. CHO: Carbohydrate, MASPs: MBL Associated Serine Proteases.

MBL2 gene

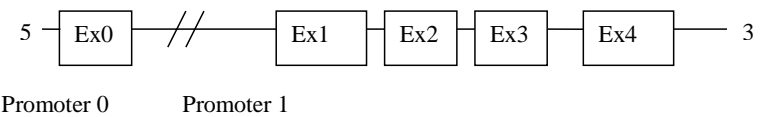

Promoter $0 \quad$ Promoter 1

MBL 25 KDa polypeptide

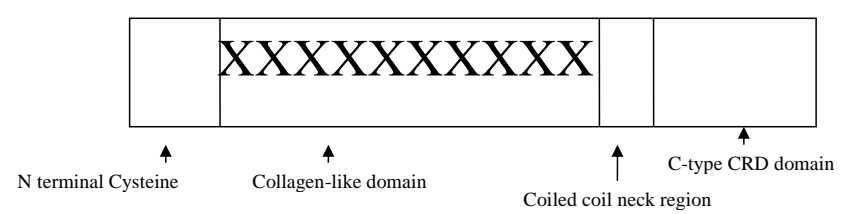

MBL tetramer

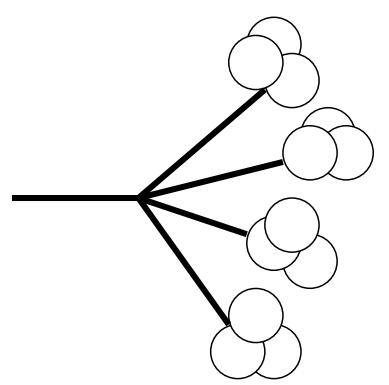

Fig. (2). Schematic representations of MBL gene structure, MBL polypeptide structure and MBL oligomeric structure. 
Mannose-Binding Lectin (MBL), also known as mannose-binding protein, was first discovered by Kawasaki in 1978 when a protein was extracted from rabbit liver using mannan particles from Saccharomyces cerevisiae as a probe [3]. Five years later MBL was isolated from the human liver [4]. MBL is mainly produced by the liver but low amounts have been found in the small intestine and testis tissue [5]. Lectins that are dependent upon the presence of calcium ions are named C-type lectins. MBL belongs to the class of collectins in the C-type lectin superfamily. It circulates throughout the body and is able to recognise a wide variety of common pathogens by repeating carbohydrate sequences present on microbial surfaces. MBL has an oligomeric structure (400-700 kDa), built of subunits that contain three identical polypeptide chains of $25 \mathrm{kDa}$ each [6,7]. Each polypeptide consists of a cysteine-rich $\mathrm{N}$ terminal region, a collagen-like region, a hydrophobic neck region, and a carbohydrate recognition domain (Fig. 2). The collagenous regions of three such chains interact to give a classical triple helix. MBL in serum primarily consists of trimers and tetramers of 9 and 12 polypeptides respectively, but the oligomers can range from dimers to hexamers [6]. These higher-order oligomers are essential for the function of MBL [8].

MBL binds carbohydrates through the c-terminal Carbohydrate-Recognition Domain (CRD) [9]. CRD is able to form bonds with hydroxyl groups on specific ligands, including mannan, $\mathrm{N}$-acetylglucosamine and glucose [10]. These carbohydrates are found on pathologic microorganisms, such as bacteria, fungi, parasitic protozoans and viruses. The CRD also recognises molecular structures of dying host cells, including nucleic acids and the metalloproteases [6]. Thus MBL acts as a recognition molecule for Pathogen-Associated Molecular Patterns (PAMPS) which play a role in the initiation and regulation of the immune response [11]. On the other hand, carbohydrates that are found on mammalian glycoproteins, such as D-galactose and sialic acid, have no affinity for MBL protein. MBL protein is, therefore, able to distinguish self from non-self in initiating the innate immune pathway.

\section{MBL2 GENE}

There are two human MBL genes. MBL-1 is a pseudogene and only MBL-2, which comprises four exons, encodes the protein product MBL [12]. The relative efficiency of MBL function for an individual is largely determined by polymorphisms within this MBL2 gene [13]. There are three point mutations or Single Nucleotide Polymorphisms (SNPs) within the first exon of MBL2 leading to MBL variant proteins [14]. They are designated ' $B$ ', ' $C$ ' and ' $D$ ', in contrast to the normal or wild-type, which is designated ' $A$ '. Allele B represents a point mutation at codon 54 causing substitution of a glycine with an aspartic acid (GGC to GAC) [14]. Allele C represents a point mutation in codon 57 causing a glycine to be substituted with a glutamic acid (GGA to GAA) [15]. Allele D represents a point mutation in codon 52 causing an arginine to be substituted with a cysteine (CGT to TGT) [16]. Allele 'B', 'C' and ' $D$ ' are collectively referred to as ' $\mathrm{O}$ '. Generally, wild-type A/A is associated with the highest MBL levels, A/O with intermediate and $\mathrm{O} / \mathrm{O}$ with low or absent $\mathrm{MBL}$. Within any given population there are different functional levels of circulating MBL, due to the differences in the frequency of MBL 2 genetic polymorphisms. B allele is frequent among Caucasians, South Americans and Asians; C allele is only frequent among Africans but is rare elsewhere, and D allele has low frequency among all populations [17]. Among normal British Caucasians, the prevalence of A/A was 60\%, A/B was $21 \%, \mathrm{~A} / \mathrm{C}$ was $5 \%, \mathrm{~A} / \mathrm{D}$ was $10 \%$ and $\mathrm{O} / \mathrm{O}$ was $4 \%$ [17].

The MBL variant proteins are unstable and probably have a shorter half-life in the circulation [18]. They have a lower molecular weight and do not effectively bind mannan or activate complement. They interfere with the formation of higher order oligomers [19]. This genetically determined MBL deficiency status influences the susceptibility, and the course of the disease, of numerous types of infectious, autoimmune, neoplastic, metabolic and cardiovascular diseases, although the conclusion is still a subject under discussion [6].

\section{MBL AND ITS ROLE IN LIVER DISEASE}

In a large normal population of 566 blood donors, the median serum MBL level was $1.3 \mu \mathrm{g} / \mathrm{ml}(\mathrm{range} 0-8.4 \mu \mathrm{g} / \mathrm{ml})$ with $10 \%$ having a very low MBL level $(<0.1 \mu \mathrm{g} / \mathrm{ml})$ [20]. Studies have shown that liver cirrhosis does not seem to have any impact on the serum MBL level as $10.7 \%$ cirrhotic patients were also found to have very low levels of MBL $(<0.1 \mu \mathrm{g} / \mathrm{ml})$. This was confirmed in a larger Hungarian study [21], which found that among patients with liver cirrhosis of various aetiologies, the median MBL level was $1.118 \mu \mathrm{g} / \mathrm{ml}$, and was not statistically different compared to the healthy control $(1.027 \mu \mathrm{g} / \mathrm{ml})$. Analysing subsets of liver disease did not reveal any particular liver disorder with lower MBL level. However, in cirrhotic patients, the risk for infection was significantly higher among MBL deficient patients and there is a shorter time to develop infectious complications when compared to non-deficient MBL cirrhotics.

In patients with Acute Liver Failure (ALF) low levels and poor functionality of the complement system has been 
known for some time [22] leading to poor outcomes as patients are more prone to infection and systemic sepsis. Recently it has been shown that there are significant changes in the lectin levels of patients with ALF and furthermore high MBL levels were associated with survival [23].

In contrast, activation of the MBL/MASP activates the complement system leading to a pro-inflammatory state resulting in deposition of excess fibrogenic extra-cellular proteins resulting in fibrosis. Data in linking MBL and liver fibrosis is limited. Nevertheless, it has been shown that among HCV patients, those with severe liver fibrosis had significant higher mean serum MBL level compared to those with mild fibrosis [24], which is thought to be due to the increased complement activation as well as the increased activity of the pro-inflammatory MBL/MASP1 complexes Recombinant MASP-1 has been shown to stimulate quiescent human stellate cells to differentiate into their active state. The cytokines produced subsequently increase extracellular matrix that is important in the pathogenesis of liver fibrosis $[25,26]$. Similarly, higher serum levels of MBL have been found in patients with advanced periportal fibrosis due to schistosomiasis [27].

\section{MBL AND HEPATITIS B VIRUS (HBV)}

Chronic Hepatitis B Virus (HBV) infection affects an estimated 240 million people worldwide and leads to a broad spectrum of liver diseases, ranging from asymptomatic carriers to self-limiting acute hepatitis, chronic infection, fulminant hepatic failure, liver cirrhosis, and hepatocellular carcinoma [28]. In a study of Chinese patients with compensated cirrhosis compared to normal controls, codon 54 mutation of MBL was associated with progression of disease in chronic hepatitis B infection and the development of spontaneous bacterial peritonitis [29]. Other studies have shown that in $\mathrm{HBV}$ infection, patients with MBL polymorphism resulting in low levels of circulating MBL are significantly more prone to viral persistence, the occurrence of cirrhosis and hepatocellular cancers, HBV acquisition, and a higher mortality in HBV associated ALF [30 - 34]. These findings, therefore, may indicate that MBL has a protective role against HBV infection. However, there are some studies which contest these findings [35, 36].

With a mother to child transmission rate of HBV in the region of $5-10 \%$, intra-uterine transmission of HBV may be related to a failure of $\mathrm{HBV}$ infected mothers to stimulate an increase in foetal MBL levels to combat the virus. It has been shown that non-infected neonates of HBV mothers have an induced increase in MBL levels conferring protection whilst neonates born with HBV have a significantly lower level of MBL [37].

\section{MBL AND HEPATITIS C VIRUS (HCV)}

Chronic Hepatitis C infection (HCV) is a worldwide public health problem. Approximately $75 \%$ of infected patients fail to clear the virus leading to chronic liver disease [38]. Patients with HCV infection and either heterozygote or homozygote codon 54 mutation have a significantly increased rate of progression to chronic hepatitis or cirrhosis suggesting that MBL polymorphisms may influence the course of HCV infection [39 - 41]. It has also been suggested that MBL-2 gene polymorphism is associated with the risk of developing pre-transplant HCV-induced hepatocellular cancer and could be utilised in predicting hepatocellular cancer risk [42]. However, some studies show conflicting results and do not support the MBL deficiency progression theory [20, 43, 44].

Response to interferon-based therapies may be determined by MBL levels as it has been shown that patients with higher levels of MBL are better responders to treatment and viral clearance [39, 44].

\section{MBL POLYMORPHISMS AND INFECTION POST LIVER TRANSPLANTATION}

Following liver transplantation, the donor's liver influences the MBL status of the recipient, as the liver is the primary source of MBL production. Therefore, if the recipient receives a liver with an exon 1 MBL2 variant genotype with decreased MBL level production and its suboptimal function, it is highly plausible that the recipient is at increased risk of infection post-liver transplantation. Several studies have suggested this to be the case, finding that the presence of MBL variant alleles in the MBL gene of the donor's liver, but not in the recipient, was associated with a strongly increased incidence of clinically significant infections after transplantation [45 - 47].

Studies have shown that recipients of MBL-deficient livers had almost a 3-fold greater likelihood of developing a clinically significant infection, particularly an increased risk of cytomegalovirus infection [46, 47]. A study has suggested that MBL-2 polymorphisms is involved in the development of acute cellular rejection post liver transplant in $\mathrm{HCV}$ positive recipients, but no other studies have been performed to observe if MBL polymorphism plays a role in non HCV cellular rejection [48]. 
However, not all studies showed the same association. A large single-centre study involving 290 donor livers failed to find any association between the donor MBL genotypes and the risk of bacterial infection after liver transplantation [49]. Cevera et al. concurred with this finding but concluded that although liver transplantation from an exon 1 MBL 2 variant genotype was not associated with a higher incidence of infection, the reduced levels of MBL contributed to poorer outcome as infectious events were of higher severity. They proposed that MBL2 genotyping be performed as deficiency could represent a major risk factor for infection-related mortality [50].

\section{POTENTIAL REASONS TO ACCOUNT FOR CONFLICTING MBL2 ASSOCIATION STUDIES}

The role of MBL in the susceptibility to various diseases, including liver diseases, is sometimes controversial. For the same disease, association, or the lack of it, have been reported.

Potential reasons to explain the conflicting results in MBL2 association studies are the techniques used for MBL2 genotyping, the size of the samples studied, and the choice of controls [51,52]. With regards to MBL2 genotyping techniques, there are currently several genotyping methods, such as multiplex PCR [53], real-time PCR with fluorogenic probes [54], and melting temperature assay [55], which are not entirely similar. Therefore there is a suggestion that a blind double check on randomly chosen samples with direct sequencing should always be considered in this kind of study [51], to ensure reliability and reproducibility of the results. With regards to the choice of control, the selection of the control population as well as the possibility of replicating the results in other ethnic groups, is a crucial point in MBL2 association studies, since the frequencies of MBL2 polymorphisms show some variability within different populations [17].

\section{THE ROLE OF MBL REPLACEMENT THERAPY IN LIVER DISEASES}

While there are some phase 1 [56 - 58] and phase 2 studies $[59,60]$ to demonstrate that MBL replacement therapy is safe and well tolerated, its clinical role has not yet been defined and it remains a research tool to date. Additionally, the lack of a well-established association between MBL deficiency and liver diseases does not suggest that there is a potential role for such replacement therapy.

\section{CONCLUSION}

Although the data is conflicting and no clear-cut association can be concluded between MBL polymorphisms and numerous liver diseases including liver fibrosis, viral hepatitis B, C and infection post-liver transplantation, the balance of opinion would be that MBL levels do contribute to disease progression and outcomes. Although plausible, MBL replacement therapy, which is still in its infancy stage, is unlikely to play any significant role in liver diseases. Further larger studies are required before MBL polymorphisms can be accepted, or refuted, as having an association with liver diseases.

\section{CONSENT FOR PUBLICATION}

Not applicable.

\section{CONFLICT OF INTEREST}

The authors declare that there is no conflict of interest, financial or otherwise.

\section{ACKNOWLEDGEMENTS}

Declared none.

\section{REFERENCES}

[1] Ikeda K, Sannoh T, Kawasaki N, Kawasaki T, Yamashina I. Serum lectin with known structure activates complement through the classical pathway. J Biol Chem 1987; 262(16): 7451-4. [PMID: 3584121]

[2] Pasupuleti M, Walse B, Nordahl EA, Mörgelin M, Malmsten M, Schmidtchen A. Preservation of antimicrobial properties of complement peptide C3a, from invertebrates to humans. J Biol Chem 2007; 282(4): 2520-8. [http://dx.doi.org/10.1074/jbc.M607848200] [PMID: 17132627]

[3] Kawasaki T, Etoh R, Yamashina I. Isolation and characterization of a mannan-binding protein from rabbit liver. Biochem Biophys Res Commun 1978; 81(3): 1018-24.

[http://dx.doi.org/10.1016/0006-291X(78)91452-3] [PMID: 666781] 
[4] Wild J, Robinson D, Winchester B. Isolation of mannose-binding proteins from human and rat liver. Biochem J 1983; $210(1)$ : 167-74. [http://dx.doi.org/10.1042/bj2100167] [PMID: 6847642]

[5] Seyfarth J, Garred P, Madsen HO. Extra-hepatic transcription of the human mannose-binding lectin gene (mbl2) and the MBL-associated serine protease 1-3 genes. Mol Immunol 2006; 43(7): 962-71.

[http://dx.doi.org/10.1016/j.molimm.2005.06.033] [PMID: 16112196]

[6] Garred P. Mannose-binding lectin genetics: From A to Z. Biochem Soc Trans 2008; 36(Pt 6): 1461-6. [http://dx.doi.org/10.1042/BST0361461] [PMID: 19021576]

[7] Teillet F, Dublet B, Andrieu JP, Gaboriaud C, Arlaud GJ, Thielens NM. The two major oligomeric forms of human mannan-binding lectin: chemical characterization, carbohydrate-binding properties, and interaction with MBL-associated serine proteases. J Immunol 2005; 174(5): $2870-7$

[http://dx.doi.org/10.4049/jimmunol.174.5.2870] [PMID: 15728497]

[8] Wallis R, Drickamer K. Molecular determinants of oligomer formation and complement fixation in mannose-binding proteins. J Biol Chem 1999; 274(6): 3580-9.

[http://dx.doi.org/10.1074/jbc.274.6.3580] [PMID: 9920905]

[9] Sheriff S, Chang CY, Ezekowitz RA. Human mannose-binding protein carbohydrate recognition domain trimerizes through a triple alphahelical coiled-coil. Nat Struct Biol 1994; 1(11): 789-94. [http://dx.doi.org/10.1038/nsb1194-789] [PMID: 7634089]

[10] Turner MW. The role of mannose-binding lectin in health and disease. Mol Immunol 2003; 40(7): 423-9. [http://dx.doi.org/10.1016/S0161-5890(03)00155-X] [PMID: 14568388]

[11] Thiel S, Frederiksen PD, Jensenius JC. Clinical manifestations of mannan-binding lectin deficiency. Mol Immunol 2006; $43(1-2)$ : 86-96. [http://dx.doi.org/10.1016/j.molimm.2005.06.018] [PMID: 16023210]

[12] Guo N, Mogues T, Weremowicz S, Morton CC, Sastry KN. The human ortholog of rhesus mannose-binding protein-A gene is an expressed pseudogene that localizes to chromosome 10. Mamm Genome 1998; 9(3): 246-9. [http://dx.doi.org/10.1007/s003359900735] [PMID: 9501312]

[13] Sastry K, Herman GA, Day L, et al. The human mannose-binding protein gene. Exon structure reveals its evolutionary relationship to a human pulmonary surfactant gene and localization to chromosome 10. J Exp Med 1989; 170(4): 1175-89. [http://dx.doi.org/10.1084/jem.170.4.1175] [PMID: 2477486]

[14] Sumiya M, Super M, Tabona P, et al. Molecular basis of opsonic defect in immunodeficient children. Lancet 1991; 337(8757): 1569-70. [http://dx.doi.org/10.1016/0140-6736(91)93263-9] [PMID: 1675710]

[15] Lipscombe RJ, Sumiya M, Hill AV, et al. High frequencies in African and non-African populations of independent mutations in the mannose binding protein gene. Hum Mol Genet 1992; 1(9): 709-15. [http://dx.doi.org/10.1093/hmg/1.9.709] [PMID: 1304173]

[16] Madsen HO, Garred P, Kurtzhals JA, et al. A new frequent allele is the missing link in the structural polymorphism of the human mannanbinding protein. Immunogenetics 1994; 40(1): 37-44. [http://dx.doi.org/10.1007/BF00163962] [PMID: 8206524]

[17] Garred P, Larsen F, Seyfarth J, Fujita R, Madsen HO. Mannose-binding lectin and its genetic variants. Genes Immun 2006; 7(2): 85-94. [http://dx.doi.org/10.1038/sj.gene.6364283] [PMID: 16395391]

[18] Naito H, Ma Y, Uemura K, Arano Y, Kawasaki T. Metabolic properties of normal and mutant mannan-binding proteins in mouse plasma. Biochem Biophys Res Commun 1999; 256(1): 231-4. [http://dx.doi.org/10.1006/bbrc.1999.0307] [PMID: 10066452]

[19] Garred P, Larsen F, Madsen HO, Koch C. Mannose-binding lectin deficiency-revisited. Mol Immunol 2003; 40(2-4): 73-84 [http://dx.doi.org/10.1016/S0161-5890(03)00104-4] [PMID: 12914814]

[20] Kilpatrick DC, Delahooke TES, Koch C, Turner ML, Hayes PC. Mannan-binding lectin and hepatitis C infection. Clin Exp Immunol 2003; 132(1): 92-5.

[http://dx.doi.org/10.1046/j.1365-2249.2003.02122.x] [PMID: 12653842]

[21] Altorjay I, Vitalis Z, Tornai I, et al. Mannose-binding lectin deficiency confers risk for bacterial infections in a large Hungarian cohort of patients with liver cirrhosis. J Hepatol 2010; 53(3): 484-91. [http://dx.doi.org/10.1016/j.jhep.2010.03.028] [PMID: 20605050]

[22] Wyke RJ, Rajkovic IA, Eddleston AL, Williams R. Defective opsonisation and complement deficiency in serum from patients with fulminant hepatic failure. Gut 1980; 21(8): 643-9. [http://dx.doi.org/10.1136/gut.21.8.643] [PMID: 7000632]

[23] Laursen TL, Sandahl TD, Støy S, et al. Circulating mannan-binding lectin, M-, L-, H-ficolin and collectin-liver-1 levels in patients with acute liver failure. Liver Int 2015; 35(3): 756-63

[http://dx.doi.org/10.1111/liv.12682] [PMID: 25203057]

[24] Brown KS, Keogh MJ, Tagiuri N, et al. Severe fibrosis in hepatitis C virus-infected patients is associated with increased activity of the mannan-binding lectin (MBL)/MBL-associated serine protease 1 (MASP-1) complex. Clin Exp Immunol 2007; 147(1): 90-8. [PMID: 17177967] 
[25] Lata J, Jurankova J, Kopacova M, Vitek P. Probiotics in hepatology. World J Gastroenterol 2011; $17(24)$ : $2890-6$. [http://dx.doi.org/10.3748/wjg.v17.i24.2890] [PMID: 21734800]

[26] Saeed A, Baloch K, Brown RJ, et al. Mannan binding lectin-associated serine protease 1 is induced by hepatitis C virus infection and activates human hepatic stellate cells. Clin Exp Immunol 2013; 174(2): 265-73. [PMID: 23841802]

[27] Silva PC, Gomes AV, Cahu GG, Coêlho MR, Muniz MT, Domingues AL. Evaluation of the cytokine mannose-binding lectin as a mediator of periportal fibrosis progression in patients with schistosomiasis. Rev Soc Bras Med Trop 2015; 48(3): 350-3. [http://dx.doi.org/10.1590/0037-8682-0309-2014] [PMID: 26108018]

[28] World Health Organisation (2016): Hepatitis B. WHO Fact Sheet 204 (Updated July. 2016. Online at http://www.who.int/mediacentre/ factsheets/ fs204/en/ (Accessed 18 Dec 2016).

[29] Yuen MF, Lau CS, Lau YL, Wong WM, Cheng CC, Lai CL. Mannose binding lectin gene mutations are associated with progression of liver disease in chronic hepatitis B infection. Hepatology 1999; 29(4): 1248-51. [http://dx.doi.org/10.1002/hep.510290417] [PMID: 10094971]

[30] Chong WP, To YF, Ip WK, et al. Mannose-binding lectin in chronic hepatitis B virus infection. Hepatology 2005; 42(5): 1037-45. [http://dx.doi.org/10.1002/hep.20891] [PMID: 16231358]

[31] Thio CL, Mosbruger T, Astemborski J, et al. Mannose binding lectin genotypes influence recovery from hepatitis B virus infection. J Virol 2005; 79(14): 9192-6.

[http://dx.doi.org/10.1128/JVI.79.14.9192-9196.2005] [PMID: 15994813]

[32] Thomas HC, Foster GR, Sumiya M, et al. Mutation of gene of mannose-binding protein associated with chronic hepatitis B viral infection. Lancet 1996; 348(9039): 1417-9.

[http://dx.doi.org/10.1016/S0140-6736(96)05409-8] [PMID: 8965590]

[33] Song H, Binh VQ, Duy DN, et al. Mannose-binding lectin gene polymorphisms and hepatitis B virus infection in Vietnamese patients. Mutat Res 2003; 522(1-2): 119-25. [http://dx.doi.org/10.1016/S0027-5107(02)00284-1] [PMID: 12517417]

[34] Hakozaki Y, Yoshiba M, Sekiyama K, et al. Mannose-binding lectin and the prognosis of fulminant hepatic failure caused by HBV infection. Liver 2002; 22(1): 29-34.

[http://dx.doi.org/10.1046/j.0106-9543.2001.01516.x] [PMID: 11906616]

[35] Höhler T, Wünschel M, Gerken G, Schneider PM, Meyer zum Büschenfelde KH, Rittner C. No association between mannose-binding lectin alleles and susceptibility to chronic hepatitis B virus infection in German patients. Exp Clin Immunogenet 1998; 15(3): 130-3. [http://dx.doi.org/10.1159/000019064] [PMID: 9813410]

[36] Bellamy R, Ruwende C, McAdam KP, et al. Mannose binding protein deficiency is not associated with malaria, hepatitis B carriage nor tuberculosis in Africans. QJM 1998; 91(1): 13-8. [http://dx.doi.org/10.1093/qjmed/91.1.13] [PMID: 9519208]

[37] Wu Y, Zhou Q, Wang H, et al. Potential role of mannose-binding lectin in intrauterine transmission of hepatitis B virus. Jpn J Infect Dis 2013; 66(5): 391-3.

[http://dx.doi.org/10.7883/yoken.66.391] [PMID: 24047736]

[38] Hajarizadeh B, Grebely J, Dore GJ. Epidemiology and natural history of HCV infection. Nat Rev Gastroenterol Hepatol 2013 ; 10(9): 553-62. [http://dx.doi.org/10.1038/nrgastro.2013.107] [PMID: 23817321]

[39] Matsushita M, Hijikata M, Ohta Y, et al. Hepatitis C virus infection and mutations of mannose-binding lectin gene MBL. Arch Virol 1998; 143(4): 645-51. [http://dx.doi.org/10.1007/s007050050320] [PMID: 9638138]

[40] Sasaki K, Tsutsumi A, Wakamiya N, et al. Mannose-binding lectin polymorphisms in patients with hepatitis C virus infection. Scand J Gastroenterol 2000; 35(9): 960-5. [http://dx.doi.org/10.1080/003655200750023039] [PMID: 11063157]

[41] Koutsounaki E, Goulielmos GN, Koulentaki M, Choulaki C, Kouroumalis E, Galanakis E. Mannose-binding lectin MBL2 gene polymorphisms and outcome of hepatitis C virus-infected patients. J Clin Immunol 2008; 28(5): 495-500. [http://dx.doi.org/10.1007/s10875-008-9201-8] [PMID: 18592362]

[42] Eurich D, Boas-Knoop S, Morawietz L, et al. Association of mannose-binding lectin-2 gene polymorphism with the development of hepatitis C-induced hepatocellular carcinoma. Liver Int 2011; 31(7): 1006-12. [http://dx.doi.org/10.1111/j.1478-3231.2011.02522.x] [PMID: 21733090]

[43] Vallinoto ACR, da Silva RFP, Hermes RB, et al. Mannose-binding lectin gene polymorphisms are not associated with susceptibility to hepatitis $C$ virus infection in the Brazilian Amazon region. Hum Immunol 2009; 70(9): 754-7. [http://dx.doi.org/10.1016/j.humimm.2009.06.014] [PMID: 19540295]

[44] Esmat S, Omran D, Sleem GA, Rashed L. Serum mannan-binding lectin in egyptian patients with chronic hepatitis C: its relation to disease progression and response to treatment. Hepat Mon 2012; 12(4): 259-64. [http://dx.doi.org/10.5812/hepatmon.704] [PMID: 22690233] 
[45] Bouwman LH, Roos A, Terpstra OT, et al. Mannose binding lectin gene polymorphisms confer a major risk for severe infections after liver transplantation. Gastroenterology 2005; 129(2): 408-14. [http://dx.doi.org/10.1016/j.gastro.2005.06.049] [PMID: 16083697]

[46] Worthley DL, Johnson DF, Eisen DP, et al. Donor mannose-binding lectin deficiency increases the likelihood of clinically significant infection after liver transplantation. Clin Infect Dis 2009; 48(4): 410-7. [http://dx.doi.org/10.1086/596313] [PMID: 19143554]

[47] de Rooij BJ, van der Beek MT, van Hoek B, et al. Mannose-binding lectin and ficolin-2 gene polymorphisms predispose to cytomegalovirus (re)infection after orthotopic liver transplantation. J Hepatol 2011; 55(4): 800-7.

[http://dx.doi.org/10.1016/j.jhep.2011.01.039] [PMID: 21334396]

[48] Eurich D, Boas-Knoop S, Yahyazadeh A, et al. Role of mannose-binding lectin-2 polymorphism in the development of acute cellular rejection after transplantation for hepatitis C virus-induced liver disease. Transpl Infect Dis 2012; 14(5): 488-95. [http://dx.doi.org/10.1111/j.1399-3062.2012.00747.x] [PMID: 22650645]

[49] Curvelo LA, de Mare-Bredemeijer E, de Canck I, et al. Does the donor mannose-binding lectin genotype really predict the risk of bacterial infections after liver transplantation? Hepatology 2011; 53(5): 1786-7. [http://dx.doi.org/10.1002/hep.24114] [PMID: 21520193]

[50] Cervera C, Balderramo D, Suárez B, et al. Donor mannose-binding lectin gene polymorphisms influence the outcome of liver transplantation. Liver Transpl 2009; 15(10): 1217-24. [http://dx.doi.org/10.1002/lt.21834] [PMID: 19790141]

[51] Segat L, Crovella S. MBL2 polymorphisms and the choice of controls for association studies: just another story? Int J Immunogenet 2011; 38(2): 101-4. [http://dx.doi.org/10.1111/j.1744-313X.2010.00981.x] [PMID: 21362144]

[52] De Melo FM, Vasconcelos LRS, do Carmo RF, Silva BS, Moura P. MBL2 polymorphism and autoimmune markers: reconsidering the complexity of biological systems in the choice of controls. Int J Immunogenet 2011; 38(2): 105-8. [http://dx.doi.org/10.1111/j.1744-313X.2010.00982.x]

[53] Skalníková H, Freiberger T, Chumchalová J, Grombiríková H, Sedivá A. Cost-effective genotyping of human MBL2 gene mutations using multiplex PCR. J Immunol Methods 2004; 295(1-2): 139-47. [http://dx.doi.org/10.1016/j.jim.2004.10.007] [PMID: 15627619]

[54] Steffensen R, Hoffmann K, Varming K. Rapid genotyping of MBL2 gene mutations using real-time PCR with fluorescent hybridisation probes. J Immunol Methods 2003; 278(1-2): 191-9. [http://dx.doi.org/10.1016/S0022-1759(03)00190-X] [PMID: 12957407]

[55] Arraes LC, de Souza PR, Bruneska D, et al. A cost-effective melting temperature assay for the detection of single-nucleotide polymorphism in the MBL2 gene of HIV-1-infected children. Braz J Med Biol Res 2006; 39(6): 719-23. [http://dx.doi.org/10.1590/S0100-879X2006000600003] [PMID: 16751976]

[56] Bang P, Laursen I, Thornberg K, et al. The pharmacokinetic profile of plasma-derived mannan-binding lectin in healthy adult volunteers and patients with Staphylococcus aureus septicaemia. Scand J Infect Dis 2008; 40(1): 44-8. [http://dx.doi.org/10.1080/00365540701522959] [PMID: 17852940]

[57] Valdimarsson H, Vikingsdottir T, Bang P, et al. Human plasma-derived mannose-binding lectin: a phase I safety and pharmacokinetic study. Scand J Immunol 2004; 59(1): 97-102. [http://dx.doi.org/10.1111/j.0300-9475.2004.01357.x] [PMID: 14723627]

[58] Valdimarsson H. Infusion of plasma-derived mannan-binding lectin (MBL) into MBL-deficient humans. Biochem Soc Trans 2003; 31(Pt 4): 768-9.

[http://dx.doi.org/10.1042/bst0310768] [PMID: 12887300]

[59] Frakking FNJ, Brouwer N, van de Wetering MD, et al. Safety and pharmacokinetics of plasma-derived Mannose-Binding Lectin (MBL) substitution in children with chemotherapy-induced neutropaenia. Eur J Cancer 2009; 45(4): 505-12. [http://dx.doi.org/10.1016/j.ejca.2008.11.036] [PMID: 19121580]

[60] Brouwer N, Frakking FNJ, van de Wetering MD, et al. Mannose-Binding Lectin (MBL) substitution: recovery of opsonic function in vivo lags behind MBL serum levels. J Immunol 2009; 183(5): 3496-504. [http://dx.doi.org/10.4049/jimmunol.0900445] [PMID: 19657091]

(C) 2018 Lo et al.

This is an open access article distributed under the terms of the Creative Commons Attribution 4.0 International Public License (CC-BY 4.0), a copy of which is available at: https://creativecommons.org/licenses/by/4.0/legalcode. This license permits unrestricted use, distribution, and reproduction in any medium, provided the original author and source are credited. 